\title{
Strategi Regulasi Emosi Kognitif pada Pra-Remaja Usia 9-12 Tahun
}

\section{Cognitive Emotion Regulation Strategies in Pre-Adolescents Ages 9-12 Years}

\author{
Adzanishari Mawaddah Rahmah ${ }^{1}$, Marisa F. Moeliono ${ }^{2}$, \\ Lenny Kendhawati ${ }^{3}$ \\ ${ }^{123}$ Fakultas Psikologi, Universitas Padjadjaran, Jatinangor-Sumedang, Indonesia \\ Email: adzanishari18001@mail.unpad.ac.id
}
KATA KUNCI Regulasi Emosi Kognitif, Anak-anak Akhir, Pra-remaja, Analisis Konten.

KEYWORDS Cognitive Emotion Regulation, Late Childhood, Pre-teens, Content Analysis.

ABSTRAK Penelitian terdahulu membuktikan bahwa strategi regulasi emosi kognitif berperan besar dalam menentukan sejauhmana situasi tidak menyenangkan berdampak pada kesehatan mental individu, khususnya pada pra-remaja. Memahami strategi regulasi emosi kognitif yang digunakan pra-remaja merupakan langkah efektif dalam penanganan preventif dan kuratif pada masalah kesehatan mental anak dan remaja yang saat ini semakin meningkat. Penelitian ini bertujuan untuk mendapatkan gambaran strategi regulasi emosi kognitif yang digunakan oleh pra-remaja berusia 9-12 tahun. Penelitian ini menggunakan pendekatan kualitatif dengan jenis penelitian deskriptif. Data dianalisis menggunakan analisis konten dilengkapi dengan penjelasan kuantitatif berupa persentase. Data dikumpulkan menggunakan kuesioner self-report berupa pertanyaan terbuka dan wawancara yang dibangun oleh pertanyaan terkait situasi tidak menyenangkan, perasaan dan emosi, serta strategi regulasi emosi kognitif yang digunakan. Didapatkan sampel sebanyak 68 partisipan usia 9-12 tahun. Hasil penelitian menunjukkan bahwa pra-remaja menggunakan strategi regulasi emosi kognitif yang dapat dikelompokkan ke dalam tujuh strategi yaitu memikirkan perasaan negatif, menyalahkan diri sendiri, menyalahkan orang lain, pasrahmenerima, memikirkan hal lain yang menyenangkan, tidak memikirkan situasi, dan mencari solusi. Dijelaskan pula kelompok strategi yang termasuk adaptif dan kurang adaptif, serta sumber stressor dan perasaan yang dianggap paling tidak menyenangkan bagi partisipan. Temuan dalam penelitian ini diharapkan dapat menjadi salah satu upaya dalam memahami 


\begin{abstract}
Previous studies have shown that cognitive emotion regulation strategies have a major role in determining how much negative life events impact on mental health for individuals, especially in pre-adolescents. By understanding the cognitive emotion regulation strategies used by pre-adolescents, it can facilitate the preventive and curative process of mental health problems in children and adolescents, given the increasing mental health problems. This study aimed to describe the cognitive emotion regulation strategies used by pre-adolescents aged 9-12 years. This descriptive qualitative study uses content analysis method as data analysis equipped with quantitative explanation in the form of percentages. Data were collected using a self-report questionnaire in the form of open-ended questions and interviews that were constructed by questions related to negative life events, negative feelings and emotions, and cognitive emotion regulation strategies used by participants. A sample of 68 normal participants aged 9-12 years were selected. The results showed that pre-adolescents used cognitive emotion regulation strategies which could be grouped into seven strategies, namely thinking about negative feelings, self-blame, others-blame, giving up/accepting, thinking about fun things, not thinking about the situations, and finding solutions. There are also further explanations regarding adaptive and less adaptive cognitive emotion strategies, the source of the stressor and the feelings that are considered the most unpleasant for the participants.
\end{abstract}

\section{PENDAHULUAN}

Regulasi emosi adalah strategi yang digunakan individu untuk menilai, menghadapi, mengelola, dan mengekspresikan emosi yang tepat pada situasi tertentu demi mendapatkan keseimbangan secara emosional (Gross, 1998). Fungsi emosi akan menjadi optimal apabila individu mampu mengelola atau meregulasi emosinya secara adaptif (Gross, 2014). Proses regulasi emosi bisa terjadi secara sadar maupun tidak sadar (Aldao dkk., 2010; Bargh \& Williams, 2007) dan dapat diaktifkan oleh diri sendiri (instrinstic) maupun oleh hal-hal di luar diri (extrinsic) (Gross, 2013).
Dalam keberfungsiannya, regulasi emosi salah satunya digunakan untuk mengurangi pengaruh negatif dari situasi yang menggugah emosi negatif atau sebagai coping (Gross, 2014). Strategi coping yang digunakan dapat diklasifikasikan sebagai strategi perilaku dan strategi kognitif. Strategi perilaku mengacu pada kemampuan individu mengelola kondisi eksternalnya agar situasi yang dihadapi sesuai dengan tujuannya, sedangkan strategi kognitif mengacu pada strategi yang memungkinkan individu mengelola tujuan, pikiran, serta penilaian terhadap situasi yang dihadapi (Davis dkk., 2016; Garnefski dkk., 2007). Strategi kognitif regulasi emosi yang 
dimaksud mengacu pada proses kognitif yang disadari (Garnefski dkk., 2001, 2007). Penelitian ini akan berfokus pada proses kognitif regulasi emosi yang disadari.

Regulasi emosi sudah mulai berkembang sejak awal kehidupan individu. Pada tiga tahun pertama kehidupan, proses regulasi emosi sebagian besar terjadi secara eksternal, dimana regulasi emosi tercapai melalui adanya perantara dari lingkungan, bukan dari keinginan anak untuk menyesuaikan responnya dengan tuntutan situasi sekitarnya (LeBlanc dkk., 2017; Sabatier dkk., 2017). Strategi regulasi emosi kognitif mulai berkembang ketika anak berusia sekitar tujuh hingga delapan tahun, dimana terjadi perubahan besar pada kemampuan kognitif anak. Anak mulai memahami bahwa orang tidak selalu mengekspresikan semua emosinya. Mereka mulai mampu menyembunyikan perasaan dan mengelola emosi sehingga emosi yang diekspresikan dapat berbeda dengan apa yang mereka rasakan sebenarnya (Pons dkk., 2004; Sabatier dkk., 2017).

Ketika berusia sembilan hingga 10 tahun, anak mulai bisa mengatur emosinya untuk menunjukkan respon yang dapat diterima secara sosial. Anak menyadari bahwa emosi positif lebih diterima secara sosial, sementara emosi negatif mengacu pada perilaku yang memalukan sehingga harus dikontrol agar tetap terkendali (Pons dkk., 2004; Sabatier dkk., 2017). Pada masa ini, anak anak mulai bisa mengelola emosinya menggunakan beragam strategi coping dalam memodifikasi perasaanya, seperti reappraisal dan mengubah sudut pandang mereka terhadap apa yang mereka hadapi (Garnefski dkk., 2007; Gross \& Thompson, 2007). Anak tidak hanya mampu mengelola emosi, namun juga menilai situasi dan menggunakan strategi coping yang menurut mereka dapat diterima lingkungannya tanpa bantuan orang dewasa. Pada masa pra-remaja, regulasi emosi sudah dapat dilakukan menggunakan strategi perilaku dan juga kognitif (Garnefski dkk., 2007; Pons dkk., 2004; Sabatier dkk., 2017).

Terkait bentuk strategi kognitif dari regulasi emosi, Garnefski dkk. (2001) menyusun konsep strategi kognitif dari regulasi emosi atau yang disebut sebagai cognitive emotion regulation (CER) menggunakan pendekatan berbasis teori pengukuran regulasi emosi terdahulu. Hasilnya menunjukkan ada sembilan strategi kognitif dalam meregulasi emosi, khususnya dalam menghadapi situasi yang menggugah emosi negatif. Konsep ini juga telah diuji pada populasi remaja dan pra-remaja dengan mengadaptasi konsep yang digambarkan pada populasi dewasa (Garnefski dkk., 2007; Garnefski \& Kraaij, 2018).

Kesembilan strategi tersebut adalah (1) self-blame (mengatribusikan situasi negatif pada diri sendiri), (2) other-blaming (mengatribusikan situasi negatif terhadap orang lain), (3) rumination (secara terus menerus terfokus pada situasi negatif dan perasaan negatif yang terkait), catastrophizing (membayangkan output terburuk dari situasi negatif), (5) acceptance (penerimaan pada situasi negatif), (6) refocus on planning (perencanaan dalam menghadapi situasi negatif), (7) positive refocusing (memikirkan hal positif atau menyenangkan), (8) positive reappraisal (memandang sisi positif dari situasi negatif), dan (9) putting into perspective (menurunkan dampak dari situasi negatif dengan cara membandingkan dengan situasi negatif lainnya) (Garnefski dkk., 2001, 2007).

Strategi regulasi emosi berhubungan dengan banyak aspek kehidupan anak, seperti pencapaian akademik, relasi sosial, hingga pemicu munculnya kondisi psikopatologis seperti kecemasan dan depresi, serta masalah kesehatan fisik (Davis dkk., 2016). Secara lebih spesifik, beberapa penelitian telah membuktikan hubungan strategi kognitif dari regulasi emosi tertentu terhadap kondisi kesehatan mental anak dan 
remaja. Garnefski dkk. (2007) melaporkan bahwa self-blaming, rumination, dan catastrophizing memprediksi simtom kecemasan yang lebih tinggi pada anak. Sedangkan positive reappraisal menjadi faktor protektif dari terjadinya kecemasan pada anak (Chan dkk., 2016). Strategi Selfblaming dan catastrophizing juga dilaporkan sebagai faktor prediktif dari depresi pada anak, sedangkan positive refocusing dan planning menjadi faktor protektif dari simptom depresi pada anak. Baru-baru ini ditemukan juga korelasi antara strategi kognitif dari regulasi emosi kognitif dengan permasalahan terkait online game pada remaja awal, walaupun penelitian tersebut masih dalam tahap awal (Kökönyei dkk., 2019).

Pemahaman mengenai strategi regulasi emosi kognitif pada kalangan praremaja menjadi penting melihat kesehatan mental anak dan remaja yang semakin terancam dengan beragamnya situasi yang dapat menggugah emosi negatif. Di Indonesia, kemunculan permasalahan kesehatan mental di kalangan anak dan remaja terlihat mengalami peningkatan yang cukup pesat. Data Riset Kesehatan Dasar (RISKESDAS) tahun 2013 yang dikeluarkan Kementerian Kesehatan menunjukkan prevalensi gangguan mental emosional yang ditunjukkan dengan gejala depresi, kecemasan, gejala somatik, gejala kognitif, dan gejala penurunan energi pada usia remaja mencapai sekitar 5,6 \% dari jumlah penduduk Indonesia. Angka ini terus meningkat hingga data RISKESDAS tahun 2018 prevalensi gangguan mental emosional pada remaja berada pada angka $10 \%$ (Kementerian Kesehatan Republik Indonesia, 2013, 2018). Pada survei internasional dilaporkan masalah kesehatan mental pada populasi anak tergolong tinggi, bahkan dikatakan satu dari lima anak mengalami masalah kesehatan mental (Buchanan-Pascall dkk., 2018; Kieling dkk., 2011). Angka ini dipercaya terus meningkat melihat faktor risiko yang semakin berkembang. Data juga menunjukkan bahwa onset dari masalah kesehatan mental ditemukan semakin dini. Salah satu penelitian epidemiologi yang dilakukan oleh Costello dkk. (2018) menyebutkan bahwa onset gangguan kecemasan rata-rata pada usia delapan tahun.

Meskipun proses regulasi emosi akan selalu melibatkan strategi kognitif dan perilaku, penanganan masalah terkait regulasi emosi dipandang lebih baik jika memandang kedua strategi secara terpisah. Hal ini dikarenakan akan lebih sulit mengubah perilaku tanpa mengubah strategi kognitif yang digunakan, karena proses kognitif akan mendahului tindakan (Garnefski dkk., 2001, 2005, 2007). Walaupun konsep strategi regulasi emosi kognitif sudah semakin banyak dikaji pada berbagai populasi pra-remaja, sebagian besar konsep yang digunakan merupakan adaptasi dari strategi yang digunakan oleh orang dewasa. Sebagaimana sembilan strategi regulasi emosi kognitif yang digunakan pada CER Questionnaire (Garnefski dkk., 2007), strategi cognitive reappraisal dan expressive suppression yang digunakan dalam emotion regulation questionnaire for children and adolescents (Gullone \& Taffe, 2012), serta kajian CER pada anak di Indonesia yang dikhususkan untuk anak dengan kanker (Fitri \& Rakhmawati, 2013).

Kajian yang mengkhususkan strategi regulasi emosi kognitif pada populasi yang lebih muda masih cenderung terbatas, khususnya pada populasi di Indonesia. Dengan lebih memahami gambaran strategi kognitif yang pra-remaja gunakan dalam meregulasi emosinya, dipercaya dapat membantu penanganan preventif dan kuratif masalah kesehatan mental anak dan remaja menjadi lebih efektif (Garnefski dkk., 2007).

Berdasarkan keterbatasan penelitian dalam regulasi emosi kognitif pada praremaja, penelitian ini bertujuan untuk 
mendapatkan gambaran strategi regulasi emosi kognitif yang digunakan pra-remaja dalam menghadapi situasi yang menggugah emosi negatif. Gambaran strategi yang dimaksud dalam penelitian ini adalah (1) situasi yang memicu emosi negatif, (2) emosi dan perasaan yang dirasa paling tidak menyenangkan, (3) strategi kognitif regulasi emosi yang digunakan, serta (4) pengelompokkan strategi kognitif regulasi emosi ke dalam strategi adaptif dan kurang adaptif berdasarkan teori.

\section{METODE PENELITIAN \\ Partisipan}

Partisipan dalam penelitian ini adalah siswa sekolah dasar berusia $9-12$ Tahun atau setingkat dengan kelas IV, V, dan VI. Total partisipan adalah 68 anak (42 laki-laki dan 26 perempuan). Pemilihan partisipan dilakukan dengan metode convenience sampling. Peneliti mendapat rekomendasi kelas dari pihak sekolah. Setelah mendapat persetujuan dari pihak orang tua dan guru, partisipan yang dipilih adalah siswa yang bersedia untuk mengikuti proses penelitian.

\section{Desain dan Prosedur}

Penelitian ini merupakan penelitian deskriptif dengan menggunakan pendekatan kualitatif. Data yang didapatkan dianalisis dengan menggunakan metode analisis konten. Analisis konten digunakan sebagai upaya peneliti memaknai data tekstual secara sistematis (Schreier, 2012). Data didapatkan dari kuesioner self-report berupa pertanyaan terbuka yang diberikan kepada responden. Partisipan diperbolehkan memberikan lebih dari satu respon untuk tiap pertanyaan. Pada jawaban yang terkesan ambigu atau kurang menjawab pertanyaan kuesioner dilakukan sesi wawancara individual dengan meminta partisipan memberi contoh dari apa yang ditulis. Pertanyaan terbuka yang dibangun dalam penelitian ini didasari pada proses strategi kognitif regulasi emosi, khususnya pada konteks situasi yang memicu emosi negatif
(Garnefski dkk., 2007). Terdapat tiga pertanyaan yang diajukan, yaitu:

(1) Hal atau situasi apa yang menurutmu paling tidak menyenangkan?

(2) Perasaan apa yang menurutmu paling tidak menyenangkan?

(3) Apa yang biasanya kamu pikirkan ketika mengalami situasi dan perasaan yang tidak menyenangkan tersebut?

\section{Teknik Analisis Data}

Pada proses konten analisis kualitatif, data yang terkumpul diolah dengan proses coding menjadi kategori secara sistematis berdasarkan 'penerjemahan' makna dan kesan yang ditangkap oleh peneliti (Schreier, 2012). Proses coding dimulai dengan membangun coding frame, mengelompokkan data ke dalam segmentasi dan unit, kemudian dilakukan evaluasi dan modifikasi terhadap coding frame hingga diperoleh hasil coding utama (Schreier, 2012). Hasil proses coding dalam penelitian dibahas dan diinterpretasikan secara kualitatif berupa pengelompokkan konten pada tema dan secara kuantitatif dengan prosentase. Hasil data yang didapatkan ditinjau secara keseluruhan dan berdasarkan jenis kelamin. Dalam upaya menjaga validitas dan reliabilitas, penelitian ini menggunakan peer debriefing dan intercoder agreement (Creswell \& Creswell, 2018). Peer debriefing dilakukan bersama dua rekan peneliti untuk melakukan review terhadap hasil penelitian dan data yang tersedia. Intercoder agreement dilakukan dengan mengulik kembali tema, kategori, dan kesimpulan serta mendiskusikannya dengan rekan kedua peneliti setelah dilakukan proses pengelompokkan data secara terpisah sehingga didapatkan kesepakatan bersama mengenai tema yang diperoleh dari penelitian.

\section{ANALISIS DAN HASIL}

Pada Tabel 1 tergambar hal-hal yang menjadi sumber emosi tidak menyenangkan bagi pra-remaja. Secara umum, gambaran sumber perasaan tidak menyenangkan yang diungkapkan lebih banyak mengarah pada 
sisi eksternal, yaitu teman $(58,8 \%)$, orang dewasa $(23,5 \%)$, dan tindakan tidak menyenangkan yang dilakukan orang lain secara umum $(14,7 \%)$. Sedangkan sumber perasaan tidak menyenangkan yang berasal dari sisi internal adalah pandangan terhadap pelajaran dan nilai di sekolah $(22,1 \%)$ serta diri sendiri $(7,4 \%)$. Bagi partisipan laki-laki pelajaran juga dipersepsikan sebagai sumber eksternal. Partisipan laki-laki dan perempuan sama-sama menjadikan teman dan orang dewasa sebagai sumber emosi negatif yang banyak diungkapkan. Pada partisipan laki-laki pelajaran dan nilai sekolah menjadi sumber emosi negatif peringkat kedua.

Tabel 1

Kategori Sumber Perasaan Tidak Menyenangkan Partisipan

\begin{tabular}{cccc}
\hline Sumber & Laki-laki $(\%)$ & Perempuan $(\%)$ & Keseluruhan $(\%)$ \\
Emosi Negatif & $\mathrm{N}=42$ & $\mathrm{~N}=26$ & $\mathrm{~N}=68$ \\
\hline Teman & $21(50)$ & $19(73,1)$ & $40(58,8)$ \\
Orang Dewasa & $8(19)$ & $8(30,8)$ & $16(23,5)$ \\
Pelajaran/Nilai & $12(28,6)$ & $3(11,5)$ & $15(22,1)$ \\
Tindakan (orang lain) & $7(16,7)$ & $3(11,5)$ & $10(14,7)$ \\
Diri Sendiri & $2(4,8)$ & $3(11,5)$ & $5(7,4)$ \\
\hline
\end{tabular}

Untuk mendapatkan gambaran lebih rinci, pada Tabel 2 dijelaskan lebih lanjut konten dari sumber perasaan tidak menyenangkan yang diungkapkan partisipan. Teman menjadi sumber perasaan tidak menyenangkan ketika terjadi ejekan, pertengkaran, pengasingan, serta persaingan. Bagi partisipan laki-laki respon teman sebagai sumber emosi negatif dikaitkan dengan teman sesama laki-laki dan pertengkaran yang lebih aktif (pertengkaran fisik, persaingan). Partisipan perempuan menggambarkan pertengkaran secara lebih pasif dan ada keterkaitan dengan teman lawan jenis. Respon pelajaran dan nilai menjadi sumber emosi negatif ketika nilai yang dihasilkan rendah dan adanya keharusan untuk remedial. Bagi partisipan laki-laki tugas yang banyak juga bisa menjadi sumber emosi negatif.
Teguran dan pembatasan kesenangan merupakan konten utama yang diungkapkan pada sumber orang dewasa. Sementara, respon tindakan lebih menekankan pada tindakan orang lain yang dirasa menimbulkan perasaan negatif. Bagi responden tindakan ini tidak terkhusus pada sosok tertentu. Tema utama yang diungkapkan mengesankan adanya rasa direndahkan oleh orang lain, seperti disalahkan, dibandingkan, tidak dipercaya, pendapat tidak didengarkan, dan dipermalukan. Bagi partisipan laki-laki, teguran menjadi perilaku yang tidak menyenangkan siapapun yang melakukannya. Diri sendiri menjadi sumber perilaku tidak menyenangkan ketika berbuat kesalahan dan gagal dalam melakukan sesuatu. 
Tabel 2

Konten Sumber Perasaan Tidak Menyenangkan

\begin{tabular}{|c|c|}
\hline $\begin{array}{c}\text { Sumber Emosi } \\
\text { Negatif }\end{array}$ & Konten \\
\hline Teman & $\begin{array}{l}\text { Laki-laki: ejekan, bertengkar, dijauhi, kalah bersaing, disakiti secara fisik, } \\
\text { tindakan teman yang mengganggu (misalnya berisik, mencontek). } \\
\text { Perempuan: mudah marah, dijauhi, berbohong, cuek, diejek, tindakan } \\
\text { teman lawan jenis yang mengganggu, bertengkar, ada yang dekat dengan } \\
\text { teman laki-laki yang disukai. }\end{array}$ \\
\hline Pelajaran dan & Laki-laki: nilai rendah, remedial, ujian, tugas yang banyak. \\
\hline Nilai & Perempuan: nilai rendah, remedial. \\
\hline Orang Dewasa & $\begin{array}{l}\text { Laki-laki: dimarahi, diceramahi, dinasehati, dilarang melakukan hal yang } \\
\text { menyenangkan. } \\
\text { Perempuan: dimarahi, disalahkan, dibatasi kesenangan. }\end{array}$ \\
\hline $\begin{array}{l}\text { Orang Lain } \\
\text { (Tindakan) }\end{array}$ & $\begin{array}{l}\text { Laki-laki: dimarahi, disalahkan, tidak dipercaya, dibandingkan, tidak } \\
\text { didengarkan. } \\
\text { Perempuan: tidak diperlukan, dipermalukan, dibandingkan. }\end{array}$ \\
\hline Diri Sendiri & Laki-laki dan perempuan: berbuat kesalahan, gagal mengerjakan sesuatu. \\
\hline
\end{tabular}

Gambar 1 memperlihatkan respon dari pertanyaan perasaan apa yang menurutmu paling tidak menyenangkan?. Berdasarkan respon yang didaparkan ditemukan bahwa perasaan tidak menyenangkan yang paling banyak diungkapkan secara umum adalah rasa marah $(57,4 \%)$, sedih $(54,4 \%)$, rasa menyesal $(38,2 \%)$, dan kecewa $(23,5 \%)$. Peringkat yang sama terlihat baik pada partisipan laki-laki maupun partisipan perempuan. Selain diungkapkan dengan kata marah, respon rasa marah diungkapkan partisipan dengan berbagai ekspresi, misalnya rasa kesal, ngambek, benci, atau pundung. Rasa menyesal dan kecewa dipisahkan dari rasa sedih berdasarkan inquiry lebih lanjut. Rasa menyesal diekspresikan dengan rasa bersalah akan tindakan yang sudah dilakukan. Rasa kecewa diekspresikan dengan tidak mendapatkan sesuatu yang diinginkan dan rasa tidak puas. Adapun emosi dan perasaan tidak menyenangkan lain yang diungkapkan oleh partisipan adalah cemas $(22,1 \%)$, takut $(20,6 \%)$, malu $(20,6 \%)$, dan iri $(11,8 \%)$.

Gambar 1

Perasaan Paling Tidak Menyenangkan bagi Partisipan

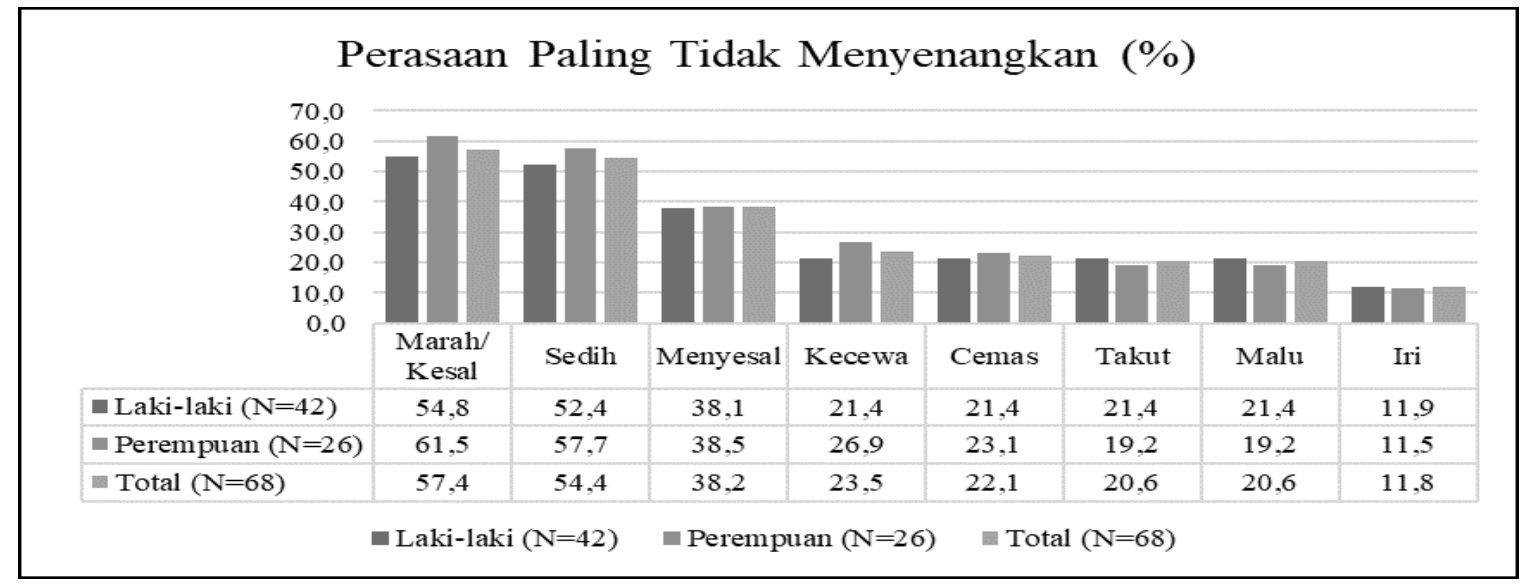


Respon partisipan terhadap pertanyaan, "Apa yang biasanya kamu pikirkan ketika mengalami situasi dan perasaan yang tidak menyenangkan?" dijelaskan pada Gambar 2. Secara keseluruhan, kategori strategi kognitif yang digunakan ialah memikirkan perasaan negatif $(29,4 \%)$, menyalahkan diri sendiri
(22,1\%), keinginan membalas dan menyalahkan orang lain $(20,6 \%)$, menerima situasi $(14,7 \%)$, memikirkan hal yang menyenangkan diri $(11,8 \%)$, berusaha tidak memikirkan situasi $(8,8 \%)$, serta memikirkan solusi yang bisa dilakukan terhadap situasi yang tidak menyenangkan $(7,4 \%)$.

Gambar 2

Kategori Strategi Kognitif Regulasi Emosi Partisipan

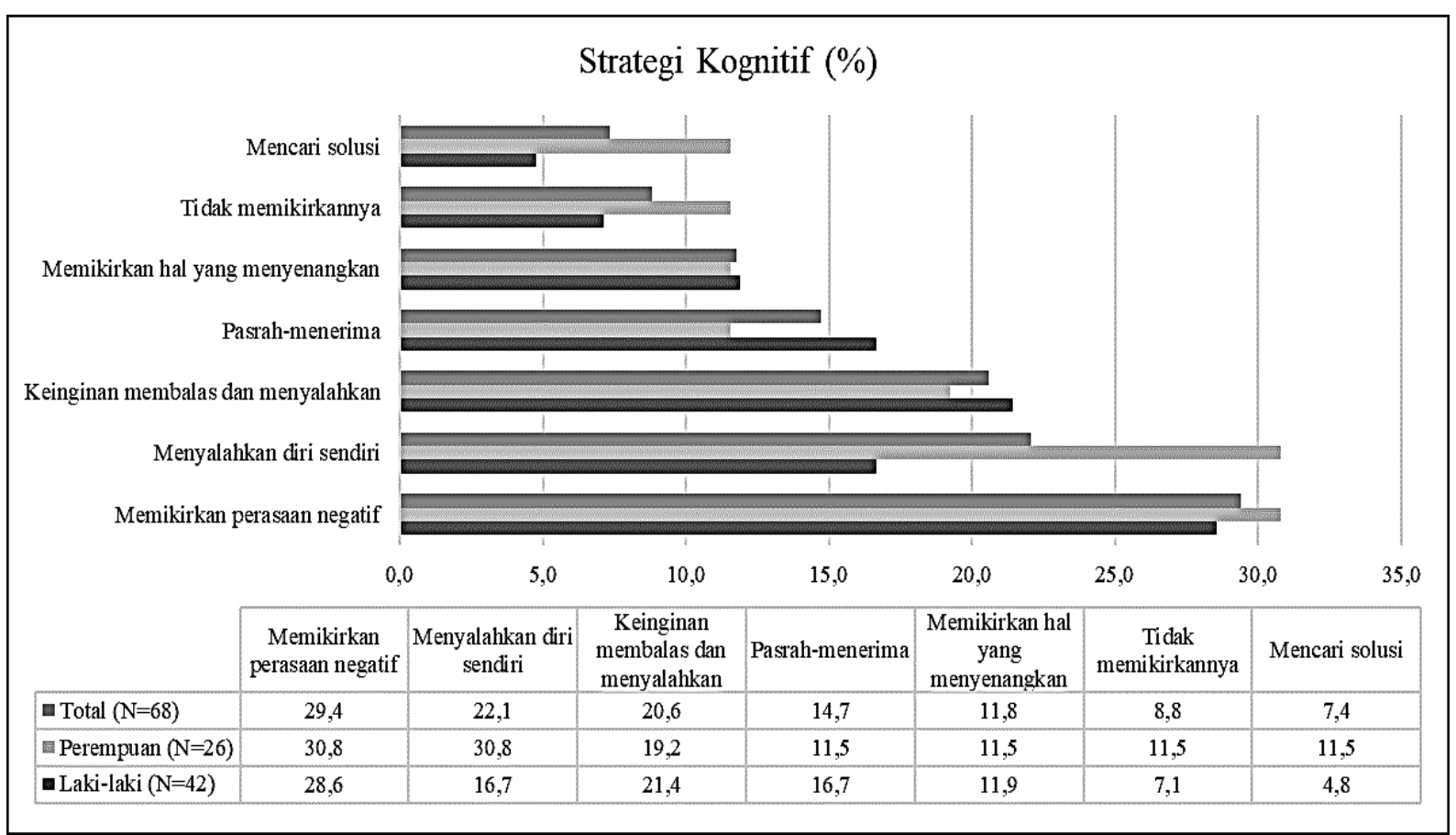

Pada partisipan laki-laki strategi kognitif yang paling banyak dimunculkan adalah memikirkan ketidaknyamanan dari perasaan negatif $(28,6 \%)$ dan keinginan untuk membalas serta menyalahkan orang lain $(20,6 \%)$. Pada partisipan perempuan, memikirkan perasaan tidak menyenangkan juga menjadi strategi kognitif yang paling banyak muncul $(30,8 \%)$ bersama dengan pemikiran menyalahkan diri sendiri $(30,8 \%)$. Deskripsi lebih lanjut terkait strategi kognitif yang partisipan ungkapkan tertera pada Tabel 3. Dalam hal ini pemikiran akan perasaan negatif bagi responden laki-laki datang dari ketidaknyaman perasaan kesal, sedih, takut, dan galau atau perasaan negatif yang sulit dideskripsikan. Bagi partisipan perempuan pemikiran perasaan negatif tidak hanya pada ketidaknyaman saat merasakan perasaan negatif, namun juga adanya pemikiran mempertanyakan perasaan negatif yang dirasakan.

Pada strategi kognitif menyalahkan diri sendiri, partisipan perempuan memberikan lebih banyak rincian dan penekanan akan kekecewaan terhadap diri sendiri dan tindakan yang sudah dilakukan yang diungkapkan dengan merasa gagal, tidak penting, dan tidak berguna. Pada partisipan laki-laki menyalahkan diri sendiri lebih menekankan pada tindakan masa lalu 
yang dianggap salah. Sementara strategi kognitif keinginan membalas dan menyalahkan orang lain lebih tergambarkan dari respon yang diungkapkan partisipan laki-laki, dimana partisipan secara eksplisit mengungkapkan aksi yang dimaksud (verbal dan fisik) serta langsung mengungkapkan bahwa situasi tidak menyenangkan terjadi karena orang lain. Pada partisipan perempuan keinginan membalas diungkapkan sebatas keinginan belum dijelaskan aksi membalas yang dimaksud.

Pada strategi pasrah dan menerima, baik partisipan laki-laki maupun perempuan mengungkapkan hal yang sama, yaitu mewajarkan situasi yang menyebabkan perasaan tidak menyenangkan dan adanya keharusan untuk menerima kejadian tersebut. Selanjutnya adalah strategi memikirkan hal menyenangkan yang tidak berkaitan situasi tidak menyenangkan. Partisipan laki-laki membayangkan interaksi menyenangkan dengan teman, keluarga, dan aktivitas yang digemari sebagai hal yang menyenangkan. Partisipan perempuan membayangkan pengalaman positif dan aktivitas yang digemari sebagai hal yang menyenangkan. Strategi tidak memikirkan hal yang tidak menyenangkan pada partisipan laki-laki lebih menekankan pada kejadian atau situasinya. Sementara pada partisipan perempuan penekanan ada pada hal-hal yang berkaitan dengan kejadian, misalnya pada orang yang bersangkutan, tindakan yang dilakukan, tempat situasi terjadi. Sebagian partisipan fokus mencari solusi yang bisa dilakukan dalam menghadapi situasi yang tidak menyenangkan. Salah satu respon yang diungkapkan adalah mencari cara untuk merubah kebiasaan harian.

Tabel 3

Deskripsi Respon Strategi Kognitif Regulasi Emosi Partisipan

\begin{tabular}{|c|c|}
\hline Strategi Kognitif & Deskripsi \\
\hline Memikirkan & Laki-laki: memikirkan ketidaknyamanan ketika merasakan perasaan tidak menyenangkan \\
\hline Perasaan Negatif & (marah, kesal, galau, takut). \\
\hline & $\begin{array}{l}\text { Perempuan: memikirkan ketidaknyaman ketika merasakan perasaan tidak menyenangkan } \\
\text { (sedih, cemas, menyesal, tidak bahagia, kesal) dan mempertanyakan perasaan (misalnya, } \\
\text { mengapa harus ngerasain seperti ini). }\end{array}$ \\
\hline $\begin{array}{l}\text { Menyalahkan Diri } \\
\text { Sendiri }\end{array}$ & $\begin{array}{l}\text { Laki-laki: merasa memiliki banyak kesalahan, menyesali, dan mempertanyaan tindakan yang } \\
\text { sudah dilakukan. }\end{array}$ \\
\hline & $\begin{array}{l}\text { Perempuan: kecewa dengan diri sendiri, menyesali tindakan, merasa gagal, diri sendiri } \\
\text { penyebab kejadian tidak menyenangkan, merasa tidak penting dan tidak berguna. }\end{array}$ \\
\hline Keinginan & Laki-laki: memikirkan keinginan untuk membalas secara verbal dan fisik (misalnya \\
\hline Membalas dan & , merasa dendam, orang lain penyebab masalah. \\
\hline $\begin{array}{l}\text { Menyalahkan } \\
\text { Orang Lain }\end{array}$ & $\begin{array}{l}\text { Perempuan: memikirkan keinginan untuk membalas perbuatan orang lain yang menyebabkan } \\
\text { masalah. }\end{array}$ \\
\hline Pasrah-Menerima & $\begin{array}{l}\text { Laki-laki dan perempuan: berpikir bahwa situasi adalah hal yang wajar terjadi, harus } \\
\text { diikhlaskan, serta sabar. }\end{array}$ \\
\hline $\begin{array}{l}\text { Memikirkan Hal } \\
\text { yang }\end{array}$ & $\begin{array}{l}\text { Laki-laki: membayangkan bermain dan bercanda dengan teman, keluarga, game, makanan, } \\
\text { dan hal seru lainnya. }\end{array}$ \\
\hline Menyenangkan & \\
\hline & \\
\hline $\begin{array}{l}\text { Memikirkan } \\
\text { Situasi }\end{array}$ & $\begin{array}{l}\text { Perempuan: tidak memikirkan hal-hal yang berkaitan dengan kejadian tidak menyenangkan } \\
\text { (orang, tempat, kejadian). }\end{array}$ \\
\hline Mencari Solusi & $\begin{array}{l}\text { Laki-laki dan perempuan: memikirkan cara untuk bisa menyelesaikan dan menghadapi } \\
\text { kejadian yang tidak menyenangkan. }\end{array}$ \\
\hline
\end{tabular}




\section{DISKUSI}

Menghadapi situasi tidak menyenangkan merupakan hal yang wajar terjadi pada pra-remaja dan individu pada umumnya. Bagaimana pra-remaja menghadapi situasi tidak menyenangkan menjadi salah satu penentu sejauhmana situasi tersebut mempengaruhi kesehatan mentalnya. Penelitian ini bertujuan menggambarkan strategi kognitif pra-remaja dalam meregulasi emosinya ketika menghadapi stressor atau situasi yang menggugah emosi dan perasaan tidak menyenangkan. Gambaran dijelaskan dengan situasi yang menimbulkan perasaan tidak menyenangkan, perasaan tidak menyenangkan, serta strategi kognitif regulasi emosi yang dijelaskan secara adaptif atau kurang adaptif. Partisipan diminta untuk menyebutkan situasi yang menimbulkan perasaan paling tidak menyenangkan, perasaan yang dirasa paling tidak menyenangkan, serta apa yang dipikirkan ketika hal tersebut terjadi. Respon partisipan dikumpulkan menggunakan kuesioner self-report berupa pertanyaan terbuka dan wawancara.

Berdasarkan respon 68 anak berusia 912 tahun semua respon terkait situasi tidak menyenangkan tergolong ke dalam relational stress experiences. Penelitian terdahulu mengelompokkan negative life events ke dalam tiga tipe psychological stress, yaitu loss events, health treat events, dan relational stress events (Garnefski dkk., 2003; Lazarus, 1999). Dikarenakan tidak ditemukan dua negative life events lainnya pada penelitian ini, pengelompokkan negative life events berfokus pada sumber stressor dari relational stress events. Sumber stressor yang paling banyak dilaporkan berasal dari luar diri anak (extrinsic) yaitu lingkungan sosial anak, seperti teman, orang tua, dan guru, serta hal yang berkaitan dengan sekolah seperti pelajaran dan nilai. Temuan juga menunjukkan bahwa sumber stressor ini paling banyak mengaktifkan rasa marah dan sedih pada partisipan. Perasaan negatif lain yang juga dilaporkan adalah rasa menyesal, kecewa, cemas, takut, malu, dan iri.

Pada penelitian ini ditemukan bahwa partisipan laki-laki dan perempuan melaporkan tujuh strategi kognitif regulasi emosi. Gambaran strategi kognitif regulasi emosi yang ditemukan adalah memikirkan perasaan negatif, menyalahkan diri sendiri, menyalahkan orang lain, pasrah-menerima, memikirkan hal lain yang menyenangkan, tidak memikirkan situasi tidak menyenangkan, dan mencari solusi. Strategi yang diungkapkan partisipan cukup dekat dengan strategi regulasi emosi kognitif yang diungkapkan pada penelitian-penelitian sebelumnya, yaitu rumination, self-blame, other-blame, acceptance, positive refocusing, cognitive avoidance, dan refocus on planning (Aldao dkk., 2010; Ayers dkk., 1996; Garnefski dkk., 2007; Smith dkk., 2016; Zalewski dkk., 2011). Penelitian ini berfokus pada gambaran strategi kognitif regulasi emosi yang diungkapkan partisipan, tidak menilai derajat dan intensitas dari strategi tersebut.

Memikirkan perasaan negatif yang dirasakan merupakan strategi kognitif yang paling banyak diungkapkan partisipan $(29,4 \%)$. Strategi ini digambarkan dengan terus menerus memikirkan perasaan tidak menyenangkan yang dirasakan. Pada partisipan perempuan strategi ini dijelaskan juga dengan mempertanyakan perasaan negatif yang dirasakan. Gambaran strategi ini cukup erat dengan strategi regulasi emosi kognitif rumination. Rumination mengacu pada proses berpikir berulang yang berfokus pada pemikiran terkait situasi, perasaan negatif, serta penyebab dan konsekuensinya (Garnefski dkk., 2007; Nolen-Hoeksema dkk., 2008; Smith dkk., 2016). Rumination termasuk ke dalam strategi regulasi emosi kognitif kurang adaptif karena berpotensi mengarahkan pada pengaruh afek negatif yang lebih intens dan menyebabkan perilaku kurang adatif (Garnefski dkk., 2007; Smith dkk., 2016), walaupun pada level moderat rumination normal untuk terjadi (Weaver dkk., 2020). 
Pada sebagian besar penelitian strategi rumination secara eksklusif dikaitkan dengan rasa sedih dikarenakan penelitian rumination pada anak lebih berfokus pada pengaruhnya terhadap simtom depresi (Smith dkk., 2016; Weaver dkk., 2020). Namun demikian, rumination juga terjadi pada rasa marah dan berpotensi menunjang munculnya agresi (Peled \& Moretti, 2007; Smith dkk., 2016). Partisipan laki-laki pada penelitian ini lebih banyak mengacu strategi memikirkan perasaan pada rasa marah yang terus menerus dirasakan. Pada partisipan perempuan perasaan yang diungkapkan lebih beragam dan terkesan lebih intens dan mengarah pada perasaan sedih, cemas, dan tidak bahagia. Perbedaan gender pada strategi rumination sebenarnya sudah cukup banyak dijelaskan pada populasi dewasa, dimana perempuan dilaporkan lebih menunjukkan level rumination yang lebih tinggi (Garnefski dkk., 2004; Muris dkk., 2004). Pada populasi anak dan remaja perempuan juga dilaporkan memiliki level rumination yang lebih tinggi, khususnya pada penelitian rumination terkait dengan kesedihan dan simtom depresi (Gomez-Baya dkk., 2017; Jose \& Brown, 2008; Peled \& Moretti, 2007). Pada penelitian terkait amarah, rumination sebagai strategi coping dilaporkan sebagai prediktor signifikan dari agresi, meskipun hanya pada partisipan lakilaki (Rey Peña \& Extremera Pacheco, 2012). Meskipun demikian, tidak ditemukan adanya perbedaan signifikan di kedua jenis kelamin pada hubungan antara bentuk rumination dengan outcome yang dihasilkan (Peled \& Moretti, 2007).

Strategi kognitif menyalahkan diri sendiri digambarkan dengan pemikiran menyalahkan, menyesali, dan kecewa pada diri sendiri dan tindakan yang telah dilakukan. Tindakan diri sendiri dianggap menjadi penyebab terjadinya peristiwa tidak menyenangkan. Strategi ini cukup dekat dengan pengertian self-blame yang mengacu pada pengatribusian perisitiwa negatif pada diri sendiri (Garnefski dkk., 2007). Sementara strategi membalas dan menyalahkan orang lain digambarkan dengan adanya pemikiran untuk membalas tindakan orang lain yang menyebabkan terjadinya situasi tidak menyenangkan. Strategi ini dijelaskan sebagai other-blame (Garnefskidkk., 2007) yang juga meliputi desire for vengeance (Yeager dkk., 2011). Kedua strategi ini dipandang sebagai strategi regulasi emosi kognitif yang kurang adaptif (Domínguez-Sánchez dkk., 2013; Garnefski dkk., 2007; Liu dkk., 2016; Orgilés dkk., 2018).

Pada penelitian ini partisipan perempuan menjelaskan lebih rinci pada strategi menyalahan diri sendiri, sementara partisipan laki-laki menjelaskan lebih rinci pada pemikiran menyalahkan dan keinginan membalas perbuatan orang lain. Meski ada perbedaan dalam kedalaman penjelasan, penelitian ini tidak bisa menyimpulkan adanya perbedaan derajat dari self-blame dan other-blame pada masing-masing jenis kelamin. Penelitian terdahulu juga melaporkan bahwa tidak ada perbedaan signifikan taraf strategi self-blame, otherblame, dan desire for vengeance diantara kedua jenis kelamin baik secara langsung maupun secara moderat (Garnefski dkk., 2004; Liu dkk., 2016; Yeager dkk., 2011).

Strategi regulasi emosi kognitif pasrah dan menerima, digambarkan sebagai pemikiran untuk mengikhlaskan situasi yang sudah terjadi. Partisipan yang mengungkapkan hal ini baik laki-laki maupun perempuan menggunakan kata ikhlas dan sabar dalam penjelasannya. Secara umum, strategi pasrah dan menerima cukup dekat dengan konsep strategi regulasi emosi acceptance dan tergolong pada strategi yang adaptif (Domínguez-Sánchez dkk., 2013; Garnefski dkk., 2007). Namun, hasil inquiry menunjukkan bahwa makna ikhlas dan sabar disini mengarah pada kesadaran bahwa situasi tidak menyenangkan sudah terjadi dan sudah terlewati, sehingga bagaimana pun harus menerimanya. Penjelasan ini menyiratkan adanya rasa putus asa dan pemikiran untuk memisahkan diri dari situasi tidak menyenangkan yang dilakukan secara pasif. Temuan yang sama juga didapatkan pada 
penelitian terdahulu, dimana secara umum strategi acceptance menunjukkan hasil yang beragam, dimana startegi ini digolongkan ke dalam strategi adaptif dan juga kurang adaptif (Aldao dkk., 2010; Liu dkk., 2016; Orgilés dkk., 2018).

Dua strategi kognitif berikutnya berkaitan dengan pengalihan pikiran dari situasi yang tidak menyenangkan. Pada strategi memikirkan hal lain yang menyenangkan, partisipan memikirkan halhal positif yang disukai sebagai pengalihan dari pemikiran negatif akan situasi yang tidak menyenangkan atau yang dikenal sebagai positive refocusing (Garnefski dkk., 2007). Sementara, strategi kognitif selanjutnya adalah berusaha untuk tidak memikirkan situasi yang tidak menyenangkan tanpa menggunakan pemikiran spesifik sebagai penggantinya atau yang dikenal sebagai cognitive avoidance (Ayers dkk., 1996; Zalewski dkk., 2011). Positive refocusing tergolong ke dalam strategi yag adaptif karena telah terbukti berhubungan secara negatif dengan berbagai simptom masalah kesehatan mental (Garnefski dkk., 2003; Garnefski \& Kraaij, 2006, 2018). Sementara, cognitive avoidance mengarah pada strategi yang kurang adaptif karena remaja dengan strategi ini berisiko lebih tinggi memiliki penyesuaian diri yang buruk terhadap stres dan krisis (Dickson dkk., 2012; Ebata \& Moos, 1991; Laugesen dkk., 2003).

Strategi terakhir yang diungkapkan dalam penelitian ini adalah pikiran mencari solusi. Strategi mencari solusi merupakan strategi yang tergolong adaptif dan digambarkan sebagai pemikiran mencari cara untuk bisa menyelesaikan dan menghadapi kejadian tidak menyenangkan yang dialami. Strategi ini dikenal pula dengan istilah refocus on planning (Garnefski dkk., 2007) atau problem solving (Aldao dkk., 2010) dan terbukti berhubungan negatif dengan berbagai simtom masalah kesehatan mental (Garnefski dkk., 2007; Garnefski \& Kraaij, 2018).
Jika melihat konsep strategi regulasi emosi kognitif Garnefski dkk. (2007), partisipan dalam penelitian ini menggambarkan enam dari sembilan strategi yang dipaparkan, ditambah dengan satu strategi lainnya yang tidak termasuk ke dalam konsep yang disebutkan, yaitu cognitive avoidance. Adapun tiga strategi regulasi emosi kognitif yang tidak terungkap dalam penelitian ini yaitu strategi catastrophizing, putting into perspective, dan positive reappraisal. Tidak ditemukannya strategi tersebut kemungkinan besar disebabkan oleh negative life events yang terbatas pada penelitian ini, hipotesis ini perlu untuk dikaji lebih lanjut pada penelitian selanjutnya.

Adapun keterbatasan dalam penelitian ini. Pertama, penelitian ini menggunakan partisipan yaitu pra-remaja pada umumnya tanpa memperhatikan karakteristik khusus seperti latar belakang keluarga, status sosial ekonomi partisipan, kondisi fisik dan psikis tertentu, dan karakteristik khusus lainnya. Sementara terdapat sejumlah faktor yang dilaporkan dapat mempengaruhi persepsi anak terhadap konflik seperti suku bangsa (Domínguez-Sánchez dkk., 2013), kondisi ekonomi keluarga, status orang tua (Butt dkk., 2014), dan kondisi khusus lainnya seperti kondisi kesehatan fisik tertentu (Firoozi dkk., 2013; Mihalca dkk., 2017; Theunissen dkk., 2011), dan kondisi mental tertentu (Andrés dkk., 2016; Legerstee dkk., 2010; Rieffe dkk., 2011). Kedua, generalisasi hasil penelitian ini terbatas pada partisipan penelitian ini, dikarenakan pemilihan partisipan yang dilakukan menggunakan teknik non-probability.

\section{SIMPULAN}

Berdasarkan respon yang diberikan partisipan pada penelitian ini, terdapat tujuh strategi regulasi emosi kognitif yang tergambarkan, dimana enam diantaranya mendekati strategi regulasi emosi kognitif yang diungkapkan oleh Garnefski dkk. (2007). Strategi regulasi emosi kognitif yang diungkapkan bersifat adaptif dan kurang adaptif. Strategi regulasi emosi kognitif yang kurang adaptif lebih banyak dilaporkan 
oleh partisipan sebagai strategi memikirkan perasaan negatif, menyalahkan diri sendiri, dan menyalahkan orang lain. Strategi regulasi emosi kognitif yang adaptif dilaporkan dengan memikirkan hal-hal yang menyenangkan dan memikirkan solusi yang bisa dilakukan untuk menghadapi situasi tidak menyenangkan. Adapun strategi yang berada di ambang antara adaptif dan kurang adaptif, yaitu pasrah/menerima dan tidak memikirkan situasi yang dirasa kurang menyenangkan. Ditemukan pula beberapa perbedaan strategi kognitif regulasi emosi antara pra-remaja laki-laki dan perempuan. Perbedaan ditunjukkan pada hal yang memicu perasaan tidak menyenangkan serta bagaimana masing-masing jenis kelamin memiliki kecenderungan untuk menggunakan strategi kognitif tertentu dalam menghadapi perasaan tidak menyenangkan yang dialami.

\section{SARAN}

Pada penelitian selanjutnya disarankan untuk mengeksplor lebih lanjut partisipan yang lebih beragam, dengan memperhatikan faktor-faktor yang dapat mempengaruhi strategi kognitif regulasi emosi pra-remaja. Hal ini perlu dilakukan agar mendapatkan gambaran situasi tidak menyenangkan dan strategi regulasi emosi kognitif yang lebih luas dan beragam. Dengan keterbatasan jumlah partisipan penelitian ini, untuk penelitian selanjutnya perlu menggunakan sampel yang lebih mewakili populasi, dengan menimbang menggunakan teknik sampling seperti stratified atau cluster sampling. Agar mendapatkan gambaran dinamika strategi kognitif regulasi emosi pra-remaja yang lebih komprehensif peneliti selanjutnya dapat melengkapi sumber data dari sudut pandang significant person pra-remaja, seperti orang tua atau guru wali kelas.

\section{DAFTAR PUSTAKA}

Aldao, A., Nolen-Hoeksema, S., \& Schweizer, S. (2010). Emotionregulation strategies across psychopathology: A meta-analytic review. Clinical Psychology Review,
$30(2)$,

https://doi.org/10.1016/j.cpr.2009.11.0

04.

Andrés, M. L., Richaud de Minzi, M. C., Castañeiras, C., Canet-Juric, L., \& Rodríguez-Carvajal, R. (2016). Neuroticism and depression in children: The role of cognitive emotion regulation strategies. The Journal of Genetic Psychology, 177(2), 55-71. https://doi.org/10.1080/00221325.2016 .1148659 .

Ayers, T. S., Sandler, I. N., West, S. G., \& Roosa, M. W. (1996). A dispositional and situational assessment of children's coping: Testing alternative models of coping. Journal of Personality, 64(4), 923-958.

https://doi.org/10.1111/j.1467-

6494.1996.tb00949.x.

Bargh, J. A., \& Williams, L. E. (2007). On the nonconscious of emotion regulation. In J. J. Gross (Ed.), Handbook of emotion regulation. The Guilford Press.

Buchanan-Pascall, S., Gray, K. M., Gordon, M., \& Melvin, G. A. (2018). Systematic review and meta-analysis of parent group interventions for primary school children aged 4-12 years with externalizing and/or internalizing problems. Child Psychiatry and Human Development, 49(2), 244-267. https://doi.org/10.1007/s10578-0170745-9.

Butt, M. M., Asif, S., Yahya, F., Fazli, S. K., \& Hania, A. (2014). Children perception of inter-parental conflicts and their cognitive emotion regulation. World Applied Sciences Journal, 31(6), 1118-1130.

https://doi.org/10.5829/idosi.wasj.201 4.31.06.494. 
Chan, S. M., Poon, S. F. O., \& Hang Tang, E. M. (2016). Daily hassles, cognitive emotion regulation and anxiety in children. Vulnerable Children and Youth Studies, 11(3), 238-250. https://doi.org/10.1080/17450128.2016 .1214887 .

Costello, E. J., Egger, H. L., Copeland, W., Erkanli, A., \& Angold, A. (2018). The developmental epidemiology of anxiety disorders: phenomenology, prevalence, and comorbidity. In W. K. Silverman \& A. P. Field (Eds.), Anxiety disorders in children and adolescents (pp. 56-75). Cambridge University Press.

https://doi.org/10.1017/CBO97805119 94920.004.

Creswell, J. W., \& Creswell, J. D. (2018). Research design: Qualitative, quantitative, and mixed methods approaches (5th ed.). SAGE Publicatons.

Davis, E. L., Quiñones-Camacho, L. E., \& Buss, K. A. (2016). The effects of distraction and reappraisal on children's parasympathetic regulation of sadness and fear. Journal of Experimental Child Psychology, 142, 344-358.

https://doi.org/10.1016/j.jecp.2015.09. 020.

Dickson, K. S., Ciesla, J. A., \& Reilly, L. C. (2012). Rumination, worry, cognitive avoidance, and behavioral avoidance: Examination of temporal effects. Behavior Therapy, 43(3), 629-640. https://doi.org/10.1016/j.beth.2011.11. 002.

Domínguez-Sánchez, F. J., Lasa-Aristu, A., Amor, P. J., \& Holgado-Tello, F. P. (2013). Psychometric properties of the spanish version of the cognitive emotion regulation questionnaire. Assessment, 20(2), 253-261. https://doi.org/10.1177/107319111039 7274.

Ebata, A. T., \& Moos, R. H. (1991). Coping and adjustment in distressed and healthy adolescents. Journal of Applied Developmental Psychology, 12(1), 3354. $\quad$ https://doi.org/10.1016/01933973(91)90029-4.

Firoozi, M., Besharat, M. A., \& Boogar, E. R. (2013). Emotional regulation and adjustment to childhood cancer: Role of the biological, psychological and social regulators on pediatric oncology adjustment. Iranian Journal of Cancer Prevention, 6(2), 65-72. /pmc/articles/PMC4142920/?report=ab stract.

Fitri, S. Y. R., \& Rakhmawati, W. (2013). Strategi regulasi emosi kognitif dan pola asuh orangtua pada anak yang menjalani kemoterapi. Jurnal Keperawatan Padjadjaran, 1(3), 196204.

https://doi.org/https://doi.org/10.24198 /jkp.v1i3.68.g65.

Garnefski, N., Boon, S., \& Kraaij, V. (2003). Relationships between cognitive strategies of adolescents and depressive symptomatology across different types of life event. Journal of Youth and Adolescence, 32(6), 401-408. https://doi.org/10.1023/A:1025994200 559.

Garnefski, N., \& Kraaij, V. (2006). Relationships between cognitive emotion regulation strategies and depressive symptoms: A comparative study of five specific samples. Personality and Individual Differences, 40(8), 1659-1669. https://doi.org/10.1016/j.paid.2005.12. 009. 
Garnefski, N., \& Kraaij, V. (2018). Specificity of relations between adolescents' cognitive emotion regulation strategies and symptoms of depression and anxiety. Cognition and Emotion, 32(7), 1401-1408. https://doi.org/10.1080/02699931.2016 .1232698 .

Garnefski, N., Kraaij, V., \& Spinhoven, P. (2001). Negative life events, cognitive emotion regulation and emotional problems. Personality and Individual Differences, 30(8), 1311-1327. https://doi.org/10.1016/S01918869(00)00113-6.

Garnefski, N., Kraaij, V., \& van Etten, M. (2005). Specificity of relations between adolescents' cognitive emotion regulation strategies and Internalizing and Externalizing psychopathology. Journal of Adolescence, 28(5), 619631.

https://doi.org/10.1016/j.adolescence.2 004.12.009.

Garnefski, N., Rieffe, C., Jellesma, F., Terwogt, M. M., \& Kraaij, V. (2007). Cognitive emotion regulation strategies and emotional problems in 9-11-yearold children: The development of an instrument. European Child and Adolescent Psychiatry, 16(1), 1-9. https://doi.org/10.1007/s00787-0060562-3.

Garnefski, N., Teerds, J., Kraaij, V., Legerstee, J., \& van den Kommer, T. (2004). Cognitive emotion regulation strategies and depressive symptoms: Differences between males and females. Personality and Individual Differences, 36(2), 267-276. https://doi.org/10.1016/S01918869(03)00083-7.

Gomez-Baya, D., Mendoza, R., Paino, S., Sanchez, A., \& Romero, N. (2017). Latent growth curve analysis of gender differences in response styles and depressive symptoms during midadolescence. Cognitive Therapy and Research, 41(2), 289-303. https://doi.org/10.1007/s10608-0169822-9.

Gross, J. J. (1998). The emerging field of emotion regulation: An integrative review. Review of General Psychology, 2(3), 271-299. https://doi.org/10.1037/1089-

2680.2.3.271.

Gross, J. J. (2013). Emotion regulation: Taking stock and moving forward. Emotion, 13(3), 359-365. https://doi.org/10.1037/a0032135.

Gross, J. J. (2014). Emotion regulation: Conceptual and empirical foundations. In J. J. Gross (Ed.), Handbook of emotion regulation (2nd ed., pp. 3-22). The Guilford Press.

Gross, J. J., \& Thompson, R. A. (2007). Emotion regulation: Conceptual foundation. In J. J. Gross (Ed.), Handbook of emotion regulation (1st ed., pp. 3-26). The Guilford Press.

Gullone, E., \& Taffe, J. (2012). The emotion regulation questionnaire for children and adolescents (ERQ-CA): A psychometric evaluation. Psychological Assessment, 24(2), 409417. https://doi.org/10.1037/a0025777.

Jose, P. E., \& Brown, I. (2008). When does the gender difference in rumination begin? Gender and age differences in the use of rumination by adolescents. Journal of Youth and Adolescence, $37(2)$ 180-192. https://doi.org/10.1007/s10964-0069166-y.

Kementerian Kesehatan Republik Indonesia. (2013). RISKESDAS 2013 dalam angka. 
Kementerian Kesehatan Republik Indonesia. (2018). Hasil utama RISKESDAS 2018.

Kieling, C., Baker-Henningham, H., Belfer, M., Conti, G., Ertem, I., Omigbodun, O., Rohde, L. A., Srinath, S., Ulkuer, N., \& Rahman, A. (2011). Child and adolescent mental health worldwide: Evidence for action. The Lancet, 378(9801), 1515-1525. https://doi.org/10.1016/S01406736(11)60827-1.

Kökönyei, G., Kocsel, N., Király, O., Griffiths, M. D., Galambos, A., Magi, A., Paksi, B., \& Demetrovics, Z. (2019). The role of cognitive emotion regulation strategies in problem gaming among adolescents: A nationally representative survey study. Frontiers in Psychiatry, 10, 114.https://doi.org/10.3389/fpsyt.2019.0 0273.

Laugesen, N., Dugas, M. J., \& Bukowski, W. M. (2003). Understanding adolescent worry: The application of a cognitive model. Journal of Abnormal Child Psychology, 31(1), 55-64. https://doi.org/10.1023/A:1021721332 181.

Lazarus, R. S. (1999). Stress and emotion: A new synthesis. Cambridge University Press.

LeBlanc, S., Essau, C. A., \& Ollendick, T. H. (2017). Emotion regulation: An introduction. In C. A. Essau, S. LeBlanc, \& T. H. Ollendick (Eds.), Emotion regulation and psychopathology in children and adolescents. Oxford University Press.

Legerstee, J. S., Garnefski, N., Jellesma, F. C., Verhulst, F. C., \& Utens, E. M. W. J. (2010). Cognitive coping and childhood anxiety disorders. European
Child and Adolescent Psychiatry, 19(2), 143-150. https://doi.org/10.1007/s00787-0090051-6.

Liu, W., Chen, L., \& Blue, P. R. (2016). Chinese adaptation and psychometric properties of the child version of the cognitive emotion regulation questionnaire. PLoS ONE, 11(2), 1-14. https://doi.org/10.1371/journal.pone.0 150206.

Mihalca, A. M., Diaconu-Gherasim, L. R., \& Butnariu, L. I. (2017). Social functioning and coping strategies in romanian and moldavian adolescents with chronic diseases. Current Psychology, 36(4), 791-800. https://doi.org/10.1007/s12144-0169468-5.

Muris, P., Roelofs, J., Meesters, C., \& Boomsma, P. (2004). Rumination and worry in nonclinical adolescents. Cognitive Therapy and Research, 28(4), 539-554. https://doi.org/10.1023/B:COTR.0000 045563.66060.3e.

Nolen-Hoeksema, S., Wisco, B. E., \& Lyubomirsky, S. (2008). Rethinking rumination. Perspectives on Psychological Science, 3(5), 400-424. https://doi.org/10.1111/j.17456924.2008.00088.x.

Orgilés, M., Morales, A., FernándezMartínez, I., Ortigosa-Quiles, J. M., \& Espada, J. P. (2018). Spanish adaptation and psychometric properties of the child version of the Cognitive Emotion Regulation Questionnaire. PLoS ONE, 13(8), 1-12. https://doi.org/10.1371/journal.pone.0 201656.

Peled, M., \& Moretti, M. M. (2007). Rumination on anger and sadness in adolescence: Fueling of fury and 
deepening of despair. Journal of Clinical Child and Adolescent Psychology, 36(1), 66-75. https://doi.org/10.1080/153744107093 36569.

Pons, F., Harris, P. L., \& de Rosnay, M. (2004). Emotion comprehension between 3 and 11 years: Developmental periods and hierarchical organization. European Journal of Developmental Psychology, 1(2), 127-152. https://doi.org/10.1080/174056203440 00022 .

Rey Peña, L., \& Extremera Pacheco, N. (2012). Physical-verbal aggression and depression in adolescents: The role of cognitive emotion regulation strategies. Universitas Psychologica, 11(4), 1245-1254.

http://journaldatabase.org/articles/phys icalverbal_aggression_depression.html

Rieffe, C., Oosterveld, P., Terwogt, M. M., Mootz, S., van Leeuwen, E., \& Stockmann, L. (2011). Emotion regulation and internalizing symptoms in children with autism spectrum disorders. Autism, 15(6), 655-670. https://doi.org/10.1177/136236131036 6571.

Sabatier, C., Restrepo Cervantes, D., Moreno Torres, M., Hoyos De los Rios, O., Palacio Sañudo, J., Sabatier, C., Restrepo Cervantes, D., Moreno Torres, M., Hoyos De los Rios, O., \& Palacio Sañudo, J. (2017). Emotion regulation in children and adolescents: concepts, processes and influences. Psicología Desde El Caribe, 34(1), 101-110.

http://www.scielo.org.co/scielo.php?sc ript=sci_arttext\&pid=S0123-

417X2017000100101\&lng=en\&nrm=i so\&tlng=en.
Schreier, M. (2012). Qualitative content analysis in practice. SAGE Publications.

Smith, S. D., Stephens, H. F., Repper, K., \& Kistner, J. A. (2016). The relationship between anger rumination and aggression in typically developing children and high-risk adolescents. Journal of Psychopathology and Behavioral Assessment, 38(4), 515527. https://doi.org/10.1007/s10862016-9542-1.

Theunissen, S. C. P. M., Rieffe, C., Kouwenberg, M., Soede, W., Briaire, J. J., \& Frijns, J. H. M. (2011). Depression in hearing-impaired children. International Journal of Pediatric Otorhinolaryngology, 75(10), 1313-1317. https://doi.org/10.1016/j.ijporl.2011.07 .023 .

Weaver, S., O'Shannessy, D., \& Donovan, C. (2020). Rumination and worry. The Encyclopedia of Child and Adolescent Development, $1-11$. https://doi.org/10.1002/978111917149 2.wecad164.

Yeager, D. S., Trzesniewski, K. H., Tirri, K., Nokelainen, P., \& Dweck, C. S. (2011). Adolescents' implicit theories predict desire for vengeance after peer conflicts: correlational and experimental evidence. Developmental Psychology, 47(4), 1090-1107. https://doi.org/10.1037/a0023769.

Zalewski, M., Lengua, L. J., Wilson, A. C., Trancik, A., \& Bazinet, A. (2011). Associations of coping and appraisal styles with emotion regulation during preadolescence. Journal of Experimental Child Psychology, 110(2), 141-158. https://doi.org/10.1016/j.jecp.2011.03. 001. 